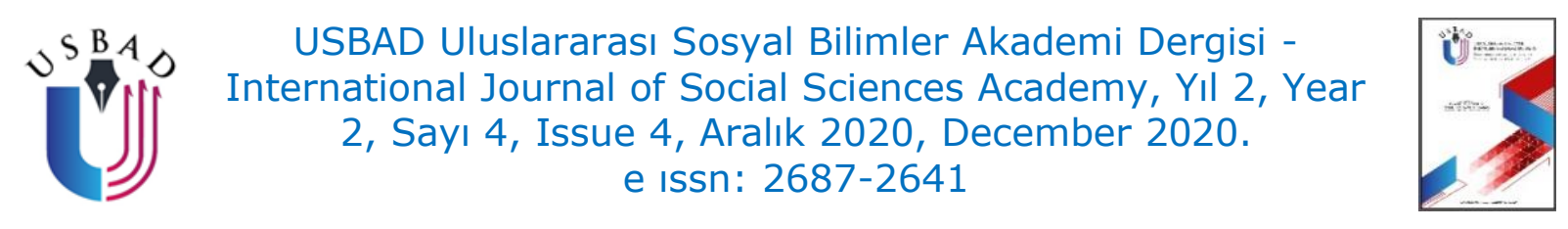

\title{
BİR BİYOGRAFİ DENEMESİ: İBRAHİM EDHEM PAŞA (1818-1893)
}

A BIOGRAPHY EXPERIMENT: IBRAHIM EDHEM PASHA (1818-1893)

\begin{abstract}
Mustafa Furkan ULUSOY
Doktora Öğrencisi, Lisansüstü Eğitim Enstitüsü, Tarih Anabilim Dalı, Fatih Sultan Mehmet Vakıf Üniversitesi, İstanbul/Türkiye.

PhD Student, Instute of Graduate Studies, History, Fatih Sultan Mehmet Vakıf University, Istanbul/Turkey.

mustafafurkanulusoy@gmail.com

ORCİD ID: 0000-0002-4094-0844
\end{abstract}

Makale bilgisi | Article Information

DOI: $10.47994 /$ usbad.815297

Makale Türü / Article Type: Araştırma Makalesi / Research Article

Geliş Tarihi / Date Received: 23.10.2020

Kabul Tarihi / Date Accepted: 18.12 .2020

Yayın Tarihi / Date Published: 20.12.2020

Yayın Sezonu / Pub Date Season: Aralık / December

Bu Makaleye Atıf İçin / To Cite This Article: Ulusoy, M. F. (2020). Bir Biyografi Denemesi: İbrahim Edhem Paşa (1818-1893). USBAD Uluslararası Sosyal Bilimler Akademi Dergisi 2(4), 1236-1252.

İntihal: Bu makale intihal.net yazılımınca taranmıştır. İntihal tespit edilmemiştir. Plagiarism: This article has been scanned by intihal.net. No plagiarism detected.

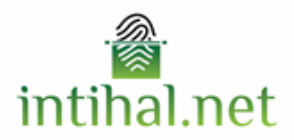

İletişim: Web: https://dergipark.org.tr/tr/pub/usbad mail: usbaddergi@gmail.com 
Öz: İbrahim Edhem Paşa, 5 Şubat 1877- 11 Ocak 1878 yılları arasında sultan II. Abdülhamid döneminde sadrazamlık yapmış bir devlet adamıdır. O'nun sadaret makamında bulunduğu yıllarda iki önemli hadise meydana gelmiştir. Meşrutiyet'in ilan edilmesiyle açılan ilk Meclis-i Mebûsan, Edhem Paşa'nın sadrazamlığı sırasında toplanmıştır. Tarihe 93 Harbi olarak geçen 1877-1878 Osmanlı-Rus Savaşı da, Edhem Paşa'nın sadrazamlık yaptığı dönemde vuku bulmuştur. Dolayısıyla Edhem Paşa, görevde kaldığı bir yıla yakın süre zarfınca, ağır meselelerle uğraşmak zorunda kalmıştır. Bu çalışmada, II. Abdülhamid'in sadrazamlarından İbrahim Edhem Paşa'nın menşei, eğitimi ve siyasi faaliyetleri üzerinde durulmuştur. Edhem Paşa'nın sadaret makamına gelinceye kadar devletin birçok kademesinde aldığı görevlerden bahsedilmiştir. Sadrazamlığı sırasında yaşanan gelişmeler ele alındıktan sonra, son olarak Paşa'nın şahsiyetine ve Osmanlı bilim dünyası için yaptığı çalışmalara değinilmiştir.

Anahtar Kelimeler: İbrahim Edhem Paşa, Sadrazam, Osmanlı Devleti, II. Abdülhamid

Abstract: İbrahim Edhem Pasha is a statesman who served as grand vizier during the reign of Sultan II. Abdulhamid Between 5 February 1877 and 11 January 1878. Two important events occurred during the years he was in the office of grand viziership. The first Parliament, which was opened with the proclamation of the Constitutional Monarchy, was convened during the Grand Vizier of Edhem Pasha. The Ottoman-Russian War of 1877-1878, which is known as the 93 War in history, took place during the period when Edhem Pasha was the grand vizier. Therefore, Edhem Pasha had to deal with serious issues during his nearly one year in office. This study is about the life of Ibrahim Edhem Pasha, one of the grand viziers of Abdulhamid II. Firstly, the origin, education and political activities of Pasha were emphasized. The duties that Edhem Pasha took at many levels of the state until he became the grand vizier were mentioned. After discussing the developments during his Grand Viziership, the personality of Pasha and his studies in the Ottoman scientific world has been mentioned.

Keywords: Ibrahim Edhem Pasha, Grand Vizier, Ottoman Empire, Abdulhamid II

\section{GİRIŞ}

Osmanlı tarihi çalışmalarında devlet adamlarının biyografileri önemli bir yer tutar. Bu biyografik çalışmalar, devlet adamlarının doğumundan ölümüne kadar şahsi hayatlarında yaşanan gelişmeleri kaynakların bize sunduğu olanaklar çerçevesinde değerlendirmektedir. Ancak kaynaklardan bize kalan anlatılar onların kişisel deneyimlerini siyasi gelişmelerle birlikte verdiğinden biyografi çalışmaları bize, 
Osmanlı İmparatorluğu'nda bürokrasi alanında yaşanan olayları daha iyi kavrama fırsatı vermektedir.

Osmanlı İmparatorluğu'nda özellikle 19. yüzyılda ciddi gelişmeler yaşanır. II. Mahmud'un imparatorluğu kurtarma çabası olarak kabul edilen modernleşme hamleleri bu yüzyıla damgasını vurur. Başlangıçta askeri reformlarla başlayan bu hamleler, devlet yapılanmasında, hukuk alanında ve eğitimde kısa sürede kendisini gösterir. Fransa'ya gönderilen Osmanlı gençleri burada aldığı eğitimden sonra yurda dönerek Osmanlı İmparatorluğunda filizlenen yeniliklerin öncüsü olurlar. Mahmud'un iktidarı merkezileştirme politikası neticesinde imparatorluk, bütün eyaletlerle arasındaki mesafeyi kapatır. Ancak payitahttaki merkezi otorite zamanla Saray'dan Bâbıâli'ye kayar. Tanzimat'la birlikte de Bâbıâli imparatorlukta tam yetki elde eder. Bu yüzden 19. yüzyıl bürokratlarının devlet yönetimindeki etkisi oldukça belirleyici ve sağlam olmuştur.

İbrahim Edhem Paşa, 19. yüzyıl modernleşme politikasının bir aşamasını temsil eder. Edhem Paşa, Fransa'ya gönderilen ilk öğrencilerden birisidir. Eğitimini tamamladıktan sonra payitahta dönmüş, Osmanlı İmparatorluğu'na uzun yıllar farklı görevlerde bulunarak hizmet etmiştir. Paşa'nın hem bu modernleşme misyonunun bir parçası olması, hem de devletin kritik bir döneminde sadaret makamında bulunması, O'nu incelemeye değer bir devlet adamı yapmaktadır.

Çalışmaya başlamadan önce İbrahim Edhem Paşa hakkında geniş bir literatür taraması yapılmıştır. Buna göre, İbnülemin Mahmut Kemal İnal'ın Son Sadrazamlar (İnal, 1982) ve Mehmed Zeki Pakalın'ın Son Sadrazamlar ve Başvekiller (Pakalın, 1942) adlı eserlerinin yanında, İsmail Hami Danişmend'in İzahlı Osmanlı Tarihi Kronolojisi (Danişmend, 1971)'nin dördüncü ve beşinci cildi ve Enver Ziya Karal'ın Osmanlı Tarihi (Karal, 2007)'nin sekizinci cildi, yararlanılan kaynakların başında gelmektedir. Ayrıca Paşa hakkında yazıımış kısa biyografilerle birlikte, Edhem Eldem'in Edhem Paşa'nın menşei üzerine yapmış olduğu çalışmadan da faydalanılmıştır (Eldem, 2010).

\section{EDHEM PAŞA'NIN MENŞEI MESELESİ}

İbrahim Edhem Paşa'nın menşei konusunda iki farklı rivayet mevcuttur. Birinci rivayete göre Edhem Paşa, Rum bir ailenin çocuğu olarak 1818 yılında Sakız Adası'nda dünyaya gelmiştir. Sakız Adası, seksen bin Hristiyana karşılık sadece bin müslümanın yaşadığı bir 
yerdir. "Etnik-i Eterya" adındaki cemiyetin tertiplediği isyanlar, 1822 yılında Sakız'a da sıçramıştır. İsyanın bastırılması için Osmanlı askerleri harekete geçmiş, olaylar durulduktan sonra birçok Rum çocuğu köle olarak Osmanlı askerinin eline geçmiştir (Danişmend, 1971: 107).

$\mathrm{Bu}$ çocuklardan birisi de Kaptan-ı Derya Koca Hüsrev Paşa (İnalcık, 1999: 41-45) tarafından satın alınır. Hüsrev Paşa, hiç çocuğu olmadığından satın aldığı köleleri kendi çocuğu gibi büyütür, iyi bir eğitim almalarını sağlardı.

Edhem Paşa'nın Hüsrev Paşa himayesine alınması hakkında bir rivayet daha vardır. Edhem Paşa'nın oğlu Halil Bey'in yazdığı biyografide yer alan bu anlatıya göre; Edhem Paşa, Hüsrev Paşa'nın hizmetlilerinden birisi olan $\mathrm{Hacl}$ Efendi tarafından Karadeniz'in Anadolu sahillerinden birisinde bulunduktan sonra, Hüsrev Paşa'nın konağına getirilmiş, Paşa'nın hanımı O'nu evladı gibi büyütmüştür. Halil Bey biyografide ayrıca, "Edhem Paşa'ya nereli olduğu sorulduğunda, kendisinin Çerkez dağlarından getirildiğini zannederdi" demektedir (Eldem, 2010: 6).

Edhem Paşa'nın Rum olduğu gerçeği bu anlatılara göre daha isabetli gözükmektedir. Paşa hakkında biyografi yazanlar da, Rum kökeni üzerinde durmakta, Anadolu sahilleri anlatısının ise doğruluğu zayıf olan bir rivayet olduğunu belirtmektedirler (İnal, 1982: 600; Danişmend, 1971: 82.).

\section{EĞİTİM HAYATI VE İLK VAZİFELER}

Edhem Paşa'nın bundan sonraki hayat hikayesi, bütün kaynaklarda hemen hemen aynı şekilde geçmektedir. Hüsrev Paşa, himayesinde bulunan kabiliyetli gençleri Sultan Mahmud'un huzuruna çıkartarak çocukları Avrupa'ya eğitime göndermek için II. Mahmud'dan izin ister. İzni aldıktan sonra, Hüseyin, Ahmet, Abdüllatif ve İbrahim Edhem'i, Fransa'ya gönderir (Gövsa, 1935: 437).

İbrahim Edhem, ilk olarak dil öğrenmek için Barbet Enstitüsü'ne kaydedilir. 1835 'de buradan mezun olduktan sonra, Yüksek Maden Okulu'na girer ve bu okuldan birincilikle mezun olur. O zamanki Fransa Kralı Louis-Phillippe, ülkesindeki yüksek okullardan birincilikle ayrılan öğrencileri huzuruna kabul etmektedir. 1839 yılında bu davete katılan Edhem, öğrenciler adına konuşma yapar. Yabancı bir öğrenci olduğundan konuşma sırasında bazı hatalar yaptığını fark eden Edhem, konuşmanın sonunda Kral'dan hatası için özür diler. Louis, "Ben böyle 
bir kusuru bir yabancı için değil Fransız için de affederim" diyerek Edhem'i rahatlatmıştır (İnal, 1982: 603).

İbrahim Edhem, eğitimini bitirdikten sonra bir müddet Avrupa'da yer alan çeşitli madenlere kendisini geliştirmek için geziler yapmıştır. Daha sonra Tirieste Limanı yoluyla İstanbul'a döner.

Edhem, yurda döndükten sonra, Meclis-i Dâr-ı Şûrâ-yı Askeri'ye miralay rütbesiyle atanır. Mühendis ve Bilim adamı olan Edhem, kendisini hiç de alışık olmadığı bir ortamda bulur. Mesleğini gerekçe göstererek görevden alınmasını ister ve ilk olarak Sarıyer Bakır Madeni müdürlüğünde bulunduktan sonra, 1842'de Gümüşhane Gümüş Maden müdürlüğüne ve 1845 'de Ergani ve Keban Madenleri başmüdürlüğüne atanır (Altınay, 1931).

Bu yıllarda henüz 17 yaşında Osmanlı tahtına geçen Abdülmecid, tahta çıktıktan üç ay sonra ilan ettirdiği Tanzimat Fermanı ile Osmanlı Devleti'nde yaşanacak değişimlerin ilk adımlarından birisini atar (Küçük, 1988: 261-262).

Abdülmecid'e sarayda özenli bir eğitim verilmektedir. Bu noktada güvenilir bir yabancı dil hocasına ihtiyaç vardır. İbrahim Edhem, bu sırada erkanı harp zabitliği ünvanını almıştır. Edhem, yedi yıllık Anadolu görevinden sonra mirliva rütbesi ile İstanbul'a döner. Rikab-I Hümâyûn'e atanan Edhem, 1841 'de ferik rütbesine yükselir. Ancak askerlikle çok ilgisi olduğu söylenemez. O'nun asıl görevi, Sultan Abdülmecid'e fen ve Fransızca dersleri vermektir (Pakalın, 1942: 405; Danişmend, 1971: 285).

Edhem Paşa'nın Saray'da yükselmesi bazı çevreleri rahatsız eder. Tophane Müşiri Damat Fethi Paşa'nın da etkisiyle Tanzimat Meclisi üyeliğine atanır. Böylece sarayla yakın ilişkisi kısıtlanmıştır.

Edhem Paşa, bazı meselelerin çözümü için müfettiş olarak 1853 yılında Sırbistan'a gönderilir. Burada gösterdiği başarıdan ötürü, Mecidi nişanı ile ödüllendirilir. Daha sonra Kırım Savaşı sonunda madalya kazananların madalya töreni için Sivastopol'a gider.

\section{EDHEM \\ PAŞA'NIN \\ SADRAZAMLIĞINA \\ KADAR VAZİFELENDİRİLDİĞİ GÖREVLER}

24 Kasım 1856'da Mustafa Reşit Paşa tarafından vezir ünvanı alan Edhem Paşa, Hâriciye nazırlığına 75.000 kuruş aylıkla tayin olunur. Ancak sadece altı ay bu makamda kaldıktan sonra, Tanzimat üyeliğine geri döner (İnal, 1982: 605). 
Edhem Paşa sadaret makamına geldiği 1877 yılına kadar devletin çeşitli makamlarında, daha çok kısa süreli hizmetlerde bulunur. $\mathrm{O}$, 1859 'da Meclis-i Vâlâ üyesidir. Edhem Paşa, sınıra yakın yere gelen Çar II. Aleksander'ı selamlamak için devletlerarası görgü ve protokol kuralları gereğince Hocabey'e gider. Aynı yıl Mahmud Nedim Paşa'nın yerine Ticaret Nazırı olur. 1861 yılında Kıbrısı Kamil Paşa'nın başvursuyla görevini başarılı bir şekilde yerine getiremediği gerekçesiyle görevden alınarak tekrar Meclis-i Vâlâ üyeliğine atanır. 1863'de Yusuf Kamil Paşa'nın kabisinde Ticaret nazırlığı görevine döner. Ticaret nezareti dışında, Maarif (Eğitim) ve Nafia (Bayındırlık) nezaretleri de Edhem Paşa'nın vekâletine bırakılır. Bir zaman sonra üzerinde sadece ticaret nazarlığı ve Osmanlı Bankası'nın denetimi kalır.

Edhem Paşa, 1866'da tüm görevlerinden alınarak Yunan sınırına yakın olan Tırhala'ya vali olarak gönderilir. Bir sene sonra Yanya valiliğine atandıktan sonra, 1868 'de Şûrâ-yı Devlet üyeliğine getirilir. Seyhun Tunaşar, Osmanlı Devleti'nde Son Dönem Mason Sadrazamları ve Yönetime Etkileri adlı kitabında, Edhem Paşa'nın Şûrâ-yı Devlet üyesi iken "Union d'Orient-Doğunun Birliği" Mason Locası'nda inisiye (tekris) edildiğini iddia etmektedir. İddiasını Fransız Ulusal Kütüphanesinde yer alan BN.FM2/867 no'lu kayda dayandırır. Locanın sicil defterinde İbrahim Edhem Paşa'nın kaydı bulunduğunu da söyler. (Tunaşar, 2003: 23). Ancak Edhem Paşa'nın mason olduğu veya olmadığı, önemli bir ayrıntı değildir. Zira o yıllarda mason locasına kayıtlı birçok devlet adamı vardır. Mason locasına kayıt olmak da, daha çok siyasi bir desteğe intiyaç duyulduğundandır.

Aynı yıl Şûrâ-yı Devlet Nafia Dairesi reisliğine, 1870'de Adliye nazırlığına ve 1871 'de Nafia nazırlığına atanr. 1874 'de Şûrâ-yı Devlet üyeliğine döner ve nihayet 1876 'da Berlin sefirliğine getirilir.

\section{TERSANE KONFERANSI}

1876 yılında Osmanlı Ordusu Sırp ordusunu yenmiş, Osmanlı'ya böylece Belgrad yolu açılmıştır. Bu durum, bütün Avrupa devletlerinin paniklemesine neden olur. Sırbistan Prensi Milan, Rus Çarı'na bir telgraf göndererek yardımını ister. Ruslar, Sırbistan'ın yenilmesiyle kendilerinin Balkanlar üzerindeki etkisinin kırılacağını görmüşlerdir. Osmanlı Devleti'ne bir ültimatom göndererek Sırplarla iki aylık kayıtsız şartsız barış yapmalarını isterler. Eğer bu istek gerçekleşmezse İstanbul'u bütün elçilik memurlarıyla beraber terk edeceklerini bildirirler. Ültimatomu kabul etmemek, durumu Ruslarla yapılacak bir 
savaşa kadar götürebileceğinden Osmanlı Devleti, ültimatomu kabul etmiş, Sırbistan ve Karadağ ile mütareke yapmıştır. Ancak Rusya'nın Balkanlar üzerinde etkili olması İngiltere'nin doğu politikasına ters bir durumdur. İngilizler, Balkan meselesini çözüme kavuşturmak için, meseleyi devletler arası bir konferansta görüşmeyi teklif eder. İngilizler ve Rusların karşılıklı restleşmelerinden sonra, Osmanlı Devleti'nin de konferans teklifini kabul etmesiyle Tersane Konferansı, 23 Aralık 1876 'da İngiltere, Rusya, Avusturya-Macaristan, Almanya, Fransa ve İtalya elçilerinin katılımıyla başlar. Konferansa katılan devletler, toplantıya delege olarak elçilerini gönderdiğinden bu konferansa elçiler konferansı da denilmiştir (Karal, 2007: 24-28).

Osmanlı Devleti adına konferansa Hâriciye Nazırı Saffet Paşa ile Berlin Büyükelçisi İbrahim Edhem Paşa delege olarak katılır. Osmanlı Devleti'nin konferansta sonunda istediğini almak için bir planı vardır. Buna göre konferans sırasında, meşrutiyet ilan edilecek, bu sayede Balkan Hristiyanlarının Kânûn-i Esâsi ile kazanacakları haklardan dolayı, Avrupalılar Balkan topraklarını Osmanlı egemenliğinde bırakacaktır. Hesaplandığı gibi meşrutiyet toplantı esnasında ilan edilir. Ancak bu gelişme, konferansa katılan delegelerin şaşkınlığı dışında, kararlar üzerinde herhangi bir etki yapamamıştır (Karal, 2007: 30).

Edhem Paşa sağlam ve iradeli duruşuyla konferansa damgasını vurmuştur. Fransa delegesi Kont Şodordi'nin Osmanlı Devleti hakkında söylediği hakaret dolu sözlere Edhem Paşa cevap vermekten çekinmemiştir. Ahmed Saip Bey, Abdülhamid'in Saltanatının İlk Günleri adlı eserinde, Fransa delegesiyle Edhem Paşa arasında geçen sert konuşmayı şöyle anlatmaktadır:

"Bir gün Edhem Paşa ile Fransız delegesi Kont Şodordi arasında olan bir çekişme az kalsın fena bir renk alıyormuş! Konuşmalar sırasında Bulgaristan'da geçen öldürme olaylarından ve zulümden söz edilirken Kont hazretleri 'böylece zulümler Türk ulusuna özgüdür' der demez, çok sert ve sinirli bir kişi olan Ethem Paşa 'Hayır yanılıyorsunuz Kont Cenapları! Böyle zulüm ve öldürmeler eger bizde oldu ise bile, yalnız Türklere özgü değildir. Fransa'da 1572 tarihinde 'Katerina Medici'nin Paris içinde, Protestanlara yaptığı zulüm kadar olamaz. Zira bir gecede altmış bin protestan öldürülmüştür' diye karşılık vermesi üzerine, Kont öfke ile ayağa kalkarak 'ben buraya hakaret görmek için gelmedim. Hâkim olmak için geldim' demiş... Ethem Paşa da gülerek, 'Hayır Kont Cenapları!... Hâkimiyetinizi hiçbir suretle 
kabul edemeyiz' cevabını vermiştir. Salisburg ile Avusturya Delegesi Kont Zeyçi araya girerek Şodordi'nin öfkesini güçlükle yatıştırmışlar, tartışmayı tatlıya bağlamışlardır. Fakat bundan sonra, General İgnatiyef de dahil olmak üzere tüm delegeler Osmanlı delegelerine karşı gayet terbiyeli davranmışlardır" (Ahmed Saip, 1983: 46-47).

1877 şubatına kadar devam Tersane Konferansı, dokuzuncu toplantıyla beraber sona erer. Konuşma ve görüşmelerin neticesinde Osmanlı Devleti diğer devletlerin sunduğu şartları reddetmiştir. Bu şartlar;

"Sırbistan'ın harbden evvelki vaziyetini muhafaza etmesi, Karadağ'a Hersek'le Arnavutluk'dan bazı yerler verilmesi, BosnaHersek'le Bulgaristan'a beşer sene müddetle tayin edilecek Hıristiyan valilerin ve kayd-i-hayatla tayin edilecek istinaf hakimlerinin intihabında devletlerden muvafakat istihsali, asayişi muhafaza için muhtelit milis kuvvetleri teşkili, Türkçe ile beraber malıalil dillerin de resmileşmesi, vergilerin kısmen hazineye mal edilip mütebakisinin mahalli ihtiyacata sarfı" (Danişmend, 1971: 292) gibi dayatmalardır.

Osmanlı Devleti bu şartları kabul etmediğini bildirmiş, böylece Tersane Konferansı sona ermiş ve delegeler ülkelerine dönmüştür (Mahmud, 1983: 211-213).

\section{MİDHAT PAŞA'NIN AZLI VE EDHEM PAŞA'NIN SADARET DÖNEMİ}

Sultan Abdülhamid'in Meşrutiyet'in ilan edildiği bu günlerde, başka planları vardır: Halkın gözünde meşrutiyetin mimarı olarak gözüken Midhat Paşa'yı devlet işlerinden uzaklaştırmak. Danişmend, Midhat Paşa'nın sadaret makamından azledilmesinin gerekçelerini şu sözlerle sıralamaktadır:

"1) Son hali'lerle iclaslardaki rollerinderı. dolayı Midhat Paşa'ya Sultan Hamid'in kat'iyyen i'timadı yoktur; 2) Yukarıdaki fıkrada gördüğümüz gibi paşa, padişahı mühlik bir harbe sürükliyecek şekilde hareket ederek hem saraya, hem devlete tahakküm etmiştir; 3) Midhat Paşa'nın bilhassa akşamları bir takım gençleri rakı masasında toplayıp 'Serair-i devletten anlara fâş etmediği şey kalmadığında' ittifak edilir : Bu noktada yalnız Mütercim-Rüşdi, Hüseyn Avni, Eğinli-Said ve Mahmud Celalüddin Paşalar gibi muasır Devlet adamlan değil, Charles Mismer vesaire 
gibi ecnebi müellifleri de müttefiktir. Midhat Paşa'nın işte bu meşhur içki alemlerinde patavatsızca söylediği sözlerin biri de cumhuriyet ilanı suretiyle Osmanlı hanedanını ıskat edip Sultan Hamid'in tabiriyle 'Reis-ül-Cumhur' olduktan sonra üçüncü Napolyon gibi kendi saltanatını ilan edivermektir! Bu vaziyete göre meşrutiyetle cumhuriyet Midhat Paşa'nın nazarında birer üzengi demektir!" (Danişmend, 1971: 296-297).

Mithat Paşa, 05.02.1877 senesinde azledilmiş, hemen o gece bir vapura bindirilerek İtalya'nın Napoli şehrine sürülmüştür. Boşalan sadaret makamına da Şûrâ-yı Devlet Reisi İbrahim Edhem Paşa getirilir. Edhem Paşa'nın sadrazam tayin edilmesi hakkında Enver Ziya Karal şunları söyler:

"Abdülhamit II.'nin Mithat Paşa gibi hürriyet sever ve meşrutiyetçi bir sadrazamdan sonra Ethem Paşa'yı sadarete getirmiş olmasının başlıca sebepleri, Ethem Paşa'nın, babasına, Fransızca öğretmenliği yapmış olması, hanedana bağlı bulunması, Bismark'ın takdirini kazanmış olduğundan Osmanlı-Rus savaşında Almanya'nın dostluğunu temin edebileceğini ümit etmiş olması ve şiddetli mizacı ile toplantıya çağırılmış olan Mebuslar Meclisinde hükümetin icraatını otorite ile savunacağını hesaba katmış olmasındandır" (Karal, 2007: 279).

Edhem Paşa'nın sadaret makamına getirilmesi Batı medyasının yakından ilgilendiği bir meseledir. Rum kökenli birisinin sadrazam olması, dış dünyanın ilgisini fazlasıyla çekmiştir. New York Times gazetesinde çıkan bir haberde, Paşa'nın Rum kimliğinden bahsedilerek, Kuzguncuk'ta ikamet eden bir papaz kardeşi olduğu da zikredilmiştir:

"Ne gariptir ki şu anda ortaya çıktığından beri en büyük buhranını yaşayan Türk İmparatorluğu'nun kaderi, Türk ırkından olmadıkları gibi, Araplar, İranlılar, Hintliler, Kafkasyalılar, Kürtler vs. gibi Müslüman ırkından da olmayan iki kişinin elindedir. Sadrazam menşei itibariyle Rumdur ve çocukken Sakız adasındaki Hıristiyan nüfusun Türk ordusu tarafından katliamı esnasından kurtarılmış, Peygamberin dininde büyütülmüştür. Kurtulabilen bir kardeşi atalarının dinine sadık kalmış ve birkaç senedir İstanbul'un Anadolu yakasındaki Kuzguncuk köyünde Ortodoks cemaatin papazı̆̆ını yapmaktadır. Bu köy sadrazam olan kardeşinin yalısının neredeyse karşısında bulunsa da, kendisiyle hiç görüşmemektedir. Çoğu din değiştiren kişi gibi -ya da dilerseniz 
çoğu sapık, çoğu dönme gibi - ve özellikle de hayatlarının erken bir döneminde İslam'la eğitilenler gibi Edhem Paşa, Muhammed'e çok ciddi bir bağlantısı olmakla beraber, fanatik olabileceğinin düşünülmesini istemeyecek kadar iyi eğitimli ve Avrupai fikirlere sahiptir." (Eldem, 2010: 8).

1877 yılının Mart ayının on dokuzunda gününde toplanan I. Meşrutiyet'in ilk Meclis-i Mebûsanı, Edhem Paşa'nın sadrazamlığında Dolmabahçe Sarayı'nda gerçekleşmiştir. Merasime katılanlar arasında Times gazetesinin muhabiri de vardır. Muhabir, izlenimlerini şu sözlerle dile getirir. Pakalın'dan aynen aktarıyorum:

"Dolmabahce sarayında dünyada misli görülmemiş bir temaşadan şimdi avdet etdim. Padişah Osmanlı parlamentosunu açdı. Avrupa gazete muhbirlerinden bazılarıyla beraber ben de 0 gün Mabeyne girmek fırsatı bulmuşdum. İki üç araba ile Galatadan hareket edip saraya geldiğimiz zaman vezirler, ulema ve sair me'murlar muvasalat etmekde idiler... Meclisi Meb'usan ve A'yan da'vet olunup otuz kadar A'yan bir gün evvel ta'yin olunmuş oldukları halde reisleri Server Paşa ve meb'usan dahi doksan kadar olarak ilmi şohret sahibi olan Ahmed Vefik Efendi ile girmişlerdi. Müslim ve gayri muslim a'za karışık olduğundan muhtelif milletlere mensub olanları şahsen görmek istediğimi yanımdaki Paşaya, söyledim, ondan 'bunlar kamilen Osmanlıdır. Artık müsluman ve yahud Rum ve Ermeni ayrı değildir' cevabını aldım. Onun bu fikrini tahsin ve tebrike layık gördüm. Zatı şahane nutku Sadrazama o da Said Paşaya verdi, o okudu. Nutuk telgrafla Avrupanın her tarafına bildirildiğinden burada tekrarına hacet görmem.'Nutkun okunması bitince hünkar hazıruna iltifat etdi, hademe 'padişahım şevketinle bin yaşa' duasını tekrar etdiği halde avdet eyledi. Bu suretle umumi meclisin açılışı hitam bulmuş ve hazır olanlar dağılmışdır. 'Padişah sade siyah elbise, ellerine de beyaz eldiven giymişdi. Alameti farika olarak murassa' nişan takmışdı. Kılıcının kabzası da murassa'dı... Açılış resmi Osmanlılara mahsus sükût, mekanet ve vekar ile icra olunmuş, hitamında toplar atıldığı gibi muzikalar da çalmışlardır." (Pakalın, 1942: 449-451).

\section{HARBİ: 1877-1878 OSMANLI RUS SAVAŞI VE EDHEM PAŞA'NIN AZLí}

Edhem Paşa'nın sadrazamlığı sırasında gerçekleşen bir diğer önemli hadise de tarihe 93 Harbi olarak geçen 1877-1878 Osmanlı-Rus 
Savaşı'dır. Tersane Konferansı kararlarının Osmanlı Devleti tarafından kabul edilmemesi üzerine Londra'da; İngiltere, Fransa, Almanya, Avusturya-Macaristan, İtalya ve Rusya'nın katıldığı bir konferans yapılmış, burada alınan İstanbul Konferans'ından pek farklı olmayan kararlar, Osmanlı Devleti'ne bildirilmiştir. Bildirilen, Meclis-i Ayan'da ve Meclis-i Mebûsan'da görüşülmüş ve kararların reddi 12 Nisan'da bir nota ile ilgili devletlere gönderilmiştir. Bu gelişmeler üzerine Rusya, 1856 tarihli Paris Anlaşması'nda yer alan Karadeniz'de tersane ve savaş gemisi bulundurmama maddesini, kabul etmediğini bildirmiş, ek olarak Osmanlı Devleti'nin kendi Ortodoks vatandaşlarına eziyet ettiğini iddia ederek Osmanlı Devleti'ne savaş açtığını bir beyanname ile Avrupa devletlerine iletmiştir:

"Babıâli, Avrupa'nın nasihatlerine saygı göstermemiştir. Hıristiyanların durumunu düzenlemek hususunda kendisine tavsiye edilmiş olan tedbirleri yerine getireceğine dair artık kendisine emniyet ve itimat gösterilemez. Balkanlar'daki devamlı kargaşalık güvenliği bozmuş ve Rusya'nın menfaatlerini sarsmıştır. Bu sebeple Rusya, Avrupa tarafından da takdir edileceğine âmin olarak Babıâli'ye karşı harp açmıştır." (Karal, 2007: 41).

Yaklaşık bir yıl süren Osmanlı Rus Savaşı, Osmanlı ordusu için bir savunma savaşıdır. Gazi Osman Paşa'nın Plevne'deki muazzam savunması, Osmanlı tarihindeki unutulmaz yerini hala korumaktadır. Osmanlı ordusunun tüm çabalarına rağmen Ruslar, Yeşilköy (Ayestefanos)'e kadar gelmişlerdir. Ruslar Osmanlı için çok ağır koşullar içeren Ayestefanos Antlaşması'nı dayatmaktadır. Ancak Avrupa ülkelerinin araya girmesiyle Berlin Antlaşması adında yeni bir anlaşma imzalanır (Danişmend, 1971: 314). Buna göre; Osmanlı Devleti, Balkanlardaki hakimiyetini kaybetmiş, Balkanlardan ve Kafkasya'dan yaklaşık bir milyon kişi, Anadolu'ya göç etmek zorunda kalmıştır. (Aydın, 1994: 498-499).

İbrahim Edhem Paşa, savaşın kaybedilmesinin sorumluları arasında gösterilmektedir:

"Edhem Paşa'nın zamanında başlıyan Rus harbinde askeri işler salahiyet sahibi merci'lerden alınarak harbin idaresi için sarayda teşkil olunan bir komisyona verilmiş olması mağlubiyet sebeplerinden birini meydana getirmiş idi. Komisyonda askerlerden başka siviller de bulunuyor, sadrazam reis addolunuyordu. (Pakalın, 1942: 470). 
Danişmend, Meclis-i Mebûsan'da yapılan gizli bir toplantı sırasında Edhem Paşa'nın büyük eleştirilere maruz kaldığını ve padişaha şikayet edildiğini belirtmektedir:

"Edhem Paşa'nın azline sebeb, yukarıdaki fıkrada gördüğümüz askeri felaketinden dolayı Meclis-i-Meb'usan'ın gizli bir celsesinde şiddetle tenkid edilmesi ve hatta padişaha şikayet edilmiş olmasıdır: Sadaret müddeti yukarıdaki senenin 5 Şubat=26 Muharrem Pazartesi gününden itibaren 11 ay, 4 gündür" (Danişmend, 1971: 309).

Edhem Paşa, bu baskılar sonucunda Abdülhamid tarafından görevinden azledilir:

"Ethem Paşa'nın çalışma arkadaşları ve saray adamları ve mebuslar, onu Osmanlı-Rus savaşının çeşitli güçlüklerinden ve felâketlerinden sorumlu tutmakla, Abdülhamit II. onu, daha fazla sadaret makamında tutamayarak çok yorgun göründüğü bahanesiyle azletmek zorunda kaldı" (Karal, 2007: 279).

Uzunçarşılı, Abdülhamid dönemi için düşünüldüğünde Edhem Paşa'nın sadarette kaldığı sürenin uzun olduğunu düşünmektedir:

"Bu tarihler yeni hükümdar olan II. Abdülhamid'in sık sık sadr-ı âzam ve başvekil değiştirmeye başladığı buhranlı devreye tesadüf etmişti; fakat kendisine itimat edilen Edhem Paşa oldukça uzun müddet yani bir seneden on beş gün eksik sadarette kalabilmişti" (Uzunçarşılı, 2013: 370).

Sultan Abdülhamid'in Edhem Paşa'yı görevden alırken takındığı tavır, Sultan'ın Paşa'ya gerçekten de çok değer verdiğini göstermektedir. Abdülhamid, Paşa'ya görevden alındığını samimi bir mektupla bildirerek adeta Paşa'nın gönlünü almaktadır:

"Sizin dirayet ve hamiyetiniz, devletimize ve bilhassa tarafımıza fartı sadakatiniz malûmumuzdur. Bu tebeddül sizi pek yorgun gördüğümden ve zamanın malum olan ağırlığındandır. Her zaman himayei mahsusam altındasınız. Yine bir memuriyetle istihdâmınız mukarrerdir. İstediğiniz vakitde nezdimize gelmeye mezunsunuz" (İnal, 1982: 617-618).

İbrahim Edhem Paşa, vazifesiz geçen 13 aylık bir süreden sonra, 1879 Mart'ında Viyana büyükelçiliğine atanmıştır. Paşa'nın buradaki görevi üç yıl sürmüş, bir süre için yeniden dinlenmek durumunda kalmıştır. 1883 yılını başlarında kurulan Küçük Sait Paşa kabinesinde, 
Dahiliye Nazırı olarak göreve başlamıştır. Yaklaşık iki buçuk sene bu vazifeyi sürdüren Edhem Paşa, Sait Paşa Hükümeti'nin düşmesiyle görevinden ayrılmıştır. Daha sonra Paris'e büyükelçi vazifesiyle gönderilmesi kararlaştırıldıysa da, bu atama gerçekleşmemiştir.

Sinan Kuneralp, Edhem Paşa'nın hayatı boyunca yapmış olduğu devlet vazifelerini tarihleriyle birlikte şu şekilde sıralamaktadır: "Hâriciye nâzırı Kasım 1856 Nisan 1857; Ticaret nâzırı Aralık 1859Temmuz 1861; Ticaret ve Nafia nâzırı Şubat-Mayıs 1863 ilâveten Maârif nâzırı Mart-Mayıs 1863; Ticaret nâzırı Mart 1865- Haziran 1866; Tirhala vâlisi Eylül 1866-Haziran 1867; Yanya vâlisi Haziran 1867-Mart 1868; Adliye nâzırı Ağustos 1870-Haziran 1871; Nâfia nâzırı Haziran 1871Ocak 1873 ilaveten Ticaret nâzırı Eylül 1871-Ağustos 1872; Nafia nâzırı Şubat 1874-Haziran 1875; Berlin büyükelçisi Nisan-Aralık 1876; Şûrâyı devlet reisi Ocak-Şubat 1877; Sadrazam Şubat 1877-Ocak 1878; Viyana büyükelçisi Mart 1879-Mart 1882; Dahiliye nâzırı Mart 1883Ekim 1885." (Kuneralp, 1999: 82).

3000 kuruş emekli maaşı bağlanan İbrahim Edhem Paşa, bundan sonraki hayatını, İstanbul'da geçirir. Sekiz sene süren emeklilik hayatından sonra, 20 Mart 1893 günü vefat eder. Edhem Paşa'nın naaşı, Üsküdar'da bulunan Mihrimah Sultan Camii haziresine defnolunmuştur. (Aydın, 1994: 419).

\section{EDHEM PAŞA'NIN ŞAHSIYYETI VE İLIM DÜNYASINA KAZANDIRDIKLARI ÜZERİNE}

Edhem Paşa'nın ele alındığı eserlerde, O'nun şahsiyeti hakkındaki yorumlar, genel anlamda birbiriyle tutarlı gözükmektedir. Edhem Paşa, namuslu ve güvenilir bir devlet adamı kimliğinin yanında, bilimsel alana katkıları olan; ancak devlet işlerinde yetersiz, asabi mizaçlı birisi olarak anılmaktadır: "Kendini yakından tanıyanlar, 'Son derece asabi olduğu her halinden, her sözünden oturup kalkışından, hatta yürüyüşünden anlaşılırdı' derlerdi" (İnal, 1982, 635). Seyhun Tunaşar'ın, Edhem Paşa'nın asabi mizacı üzerine söylediği sözler oldukça ilginçtir: "O devirlerde iyi yetişmiş, eğitim görmüş yetenekli personelin de bulunmadığı göz önüne alınırsa İ. Edhem Paşa'nın o kadar sinirli oluşunun nedeni ortaya çıkıyor. Bu kadar ağır yükün altında çıldırmamasını hayretle karşılamak gerekiyor." (Tunaşar, 2003: 64).

Şimdi Edhem Paşa'nın kişiliği hakkında yorumda bulunan çalışmalardan bahsedelim.

İbrahim Alaettin, Edhem Paşa için; 
"Memleketin siyasî hayatında mühim bir rol oynamamışsa da daima dürüst ve namuslu kalmıştı. İdare teşkilâtında muvaffakiyetli bir ilim adamı idi" demektedir (Gövsa, 1935: 437).

Enver Ziya Karal, Edhem Paşa'nın şahsiyetini, Osmanlı Tarihi eserinde şu sözlerle anlatır:

"Ethem Paşa, karakter itibariyle namuslu, doğru, kimseye kin beslemeyen bir zattı. Fransızcayı mükemmel denecek derecede bilmekte idi. Batının diplomasi usul ve kaidelerine de vakıf idi. Bulunduğu memuriyetlerde bilgiler ve tecrübeler kazanmıştı. Berlin elçiliği esnasında, Bismarck'ın bile takdirini kazanmıştı. Bununla beraber son derecede asabi idi. En ufak şeylerden hiddetlenir, bağırıp çağırırdı. Bu mizacı sebebiyle kendisine deli Corci lâkabı verilmişti. Kölelikten yetiştiği için saraya bağı idi. Abdülhamit II.'yi memnun etmek, onun itimadını kazanmak başlıca düşüncesi idi. Bundan ötürü Kanunu Esasinin kurulmasının amaç tuttuğu meşrutiyet devrinin sadrazamı olabilecek vasıflara ve mesleğe sahip değildi." (Karal, 2007: 278279).

Sicill-i Osmani'de, Edhem Paşa kısa ama öz bir şekilde tanıtılmaktadır:

"Rumca ve Fransızcayı bilir, tabii ilimlere ve felsefeye vakıf, doğru, iffetli, sert mizaçlı, edip olup nafia işlerinde hizmeti görülmüştü" (Süreyya, 1996: 108).

Mahir Aydın, Türkiye Diyanet Vakfı İslam Ansiklopedisi'nde Edhem Paşa maddesinde, benzer noktalara temas etmektedir:

"İbrahim Edhem Paşa, asabi mizacı ve devlet meselelerindeki yetersizliğine rağmen namuslu, dürüst, devlete sadık bir kişiydi. Maden mühendisliği konusunda olduğu gibi tabii ilimlerde de derin bilgi sahibiydi. Çok iyi derecedeki Fransızcasının yanı sıra Almancaya da aşina idi... Yazıda sade ve kısa cümleler kullanmayı tercih eden ve muhalifleri tarafından "Deli Corci" lakabıyla anılan İbrahim Edhem Paşa dindarlığı ile de tanınmıştır." (Aydın, 1994: 419).

Edhem Eldem, Fransız konsolosluğunun resmi sitesinde yer alan Edhem Paşa hakkındaki yazısında, Paşa'nın Fransa'ya yakınlığından söz etmekte, O'nun bir medeniyet projesi olduğunu söylemektedir: 
"Fransa'yla olan bağlarına gelince, İbrahim Edhem talebeliği zamanındaki Fransız diplomatlarını ve öğretmeni Barbet'yi haklı çıkarmıştı. Osmanlı erkanı arasında Fransızcayı ana dili gibi konuşmasıyla ün salan bu devlet adamı Fransa ve Fransız kültür ve bilim dünyasıyla hep yakın temasta kalmıştır. Osman Hamdi Bey'in her iki evliliğini de Fransızlarla yapmış olması, gerek resmi gerek özel hayatında Fransızca ve Fransa'ya gösterdiği bağlıık, 1831 'de "Edhem" adı verilmiş yetim bir Rum çocuğuyla başlayan "medeniyet projesi"nin ne denli derin izler bıraktığını göstermeye yeterlidir" (Ambafrance, 2018).

Edhem Paşa, yaptığı çalışmalarla Osmanlı bilim ve kültür dünyasına büyük katkıda bulunmuştur. Cemiyet-i İlmiye-i Osmaniye'nin yayın organı Mecmuâ-i Fünun'da, "Medhal-i İlm-i Jeoloji" başlığı altında jeoloji, madenler, hava ve su, gazlar, tuzlar, eterler, buhar, nehirler ve denizler, yakamozlar, ağaçlar vb. konular üzerine Edhem Paşa'nın birçok makalesi yayımlanmıştır. Paşa, mesâhât (yer ölçümü), ekyal (kileler, hububat ölçekleri) ve evzan (tartılar) gibi ölçümlerle ilgili tüzükler çıkartmıştır. Bu alandaki girişimler, modern olarak ancak Cumhuriyet döneminde uygulamaya konulmuştur. Bunların yanında Edhem Paşa, Daruşşafaka'nın kurulmasına, Matbaa-i Âmire'nin ve Rasathane'nin geliştirilmesine sağladığı katkıyla, modern teknik araçların ülkede yaygın hale gelmesinde büyük rol oynamıştır. (Koç, 1992: 29).

1873 Viyana Dünya Sergisi'nde iki Osmanlı eserinin yayınlanması, Edhem Paşa'nın gayretleriyle olmuştur. Usul-i Mi'mar-i Osman-i ve Elbise-i Osmaniyye adındaki bu iki ünlü eser, sergide yayınlanmış, hatta Edhem Paşa, Usul-i Mi'mari Osman-i'yi Ahmet Vefik Paşa'yla birlikte kaleme almıştır. Viyana Sergisi için dünyanın farklı noktalarından gelen elbiseler, Edhem Paşa'nın konağında toplanarak, pek çok kişiye giydirilirmiş, Sebah et Joallier de, bunların fotoğraflarını çekmiştir. (Ergin, 1977: 1866).

Edhem Paşa, tarihe de merakı olan bir şahsiyettir. Kendi olanakları içinde topladığı belgeler neticesinde yazmaya başladığı "Endülüs Tarihi" adlı eserin ilk cildini tamamlamış, kalan cildi kaleme alması için Ziya Paşa'yı görevlendirmiş, Ziya Paşa da eseri, iki cilt halinde yayımlamıştır.

Edhem Paşa'nın Osman Hamdi, İsmail Galip ve Halil Edhem adındaki üç oğlunun, devlete kültür, bilim ve sanat alanında büyük 
hizmetleri olmuştur. Osman Hamdi Bey ressam, arkeolog ve müzecidir. İsmail Galip, bilimsel nümizmatiğinin (sikke ve madalya bilgisi) kurucusudur. Halil Edhem ise, yurtdışında biyoloji ve kimya eğitimi almıştır. 1909 yılında İstanbul Şehreminiliği yaptıktan sonra, 1910'da müzeler müdürlüğü görevinde bulunmuştur. Emekli olduktan sonra da, İstanbul'dan milletvekili olarak seçilmiştir. (Uzunçarşılı, 2010).

\section{SONUÇ}

Bu çalışmada, II. Abdülhamid'in ilk sadrazamlarından birisi olan İbrahim Edhem Paşa'nın hayatı, eldeki kaynakların değerlendirilmesi sonucunda anlaşılmaya çalışılmıştır. Paşa'nın hayatına baktığımızda, imparatorluğa sadakatle hizmet etme isteği açıkça gözükür. Ancak devlet yönetiminde sadakat tek başına yetebilen bir meziyet değildir. Sadık devlet adamı kişiliği O'nu sadrazamlığa taşıyan bir özellik olarak ön plana çıkar. Ancak böyle bir makamı temsil etmek, siyasi kişiliğin kuvvetli olmasını gerektirir. Ancak Edhem Paşa'nın siyasi tecrübesi böyle bir görevi yürütebilmesi için yeterli gözükmüyor.

Ancak Edhem Paşa, siyasi hayatındaki başarızığını, ilim ve sanat alanında yaptığı çalışmalarla kapatmıştır. Tabii ilimler üzerine Mecmuâi Fünun'da makaleler yazması, ülkedeki bilim kurumlarını faaliyetine geçirmesi ve Viyana Sergisi'nde iki Osmanlı eserini yayınlatması, Edhem Paşa'nın bilim, kültür ve sanata verdiği önemi göstermektedir. 19. yüzyıl boyunca devam eden Fransa'ya öğrenci gönderme geleneğinin ilk temsilcilerinden birisi olması Paşa'nın bu alandaki başarılarının sebeplerinden birisidir. Nihayetinde Edhem Paşa, Osmanlı ilim ve bilim dünyası için son derece kıymetli bir figürdür.

\section{KAYNAKÇA}

Ahmed Saip. (1983). Abdülhamid'in Saltanatının İlk Günleri (Yay.). Ruhi Turfan, İstanbul: Erler Matbaası.

Danişmend, İ. H. (1971). İzahlı Osmanlı Tarihi Kronolojisi Cilt: 4, İstanbul, Türkiye Yayınevi.

Danişmend, İ. H. (1971). İzahlı Osmanlı Tarihi Kronolojisi: Osmanlı Devlet Erkanı, Cilt: 5, İstanbul: Türkiye Yayınevi.

Ergin, O. N. (1977). Türkiye Maarif Tarihi, Cilt: 5, İstanbul: Eser Matbaası.

Gövsa, İ. A. (1935). Meşhur Adamlar Hayatları-Eserleri, Cilt: 2, İstanbul. 
İnal, İ. M. K. (1982). Son Sadrazamlar, Cilt: 2, İstanbul: Dergah Yayınları.

Karal, E. Z. (2007). Osmanlı Tarihi: Birinci Meşrutiyet ve İstibdat Devirleri (1876-1907), Cilt: 8, Ankara: Türk Tarih Kurumu Yayınları.

Kuneralp, S. (1999). Son Dönem Osmanlı Erkan ve Ricali (1839-1922) Prosopografik Rehber. İstanbul: İsis Yayınları.

Mahmud, C. P. (1983). Mirât-ı Hâkikat: Tarih-i Hakikatlerin Aynası (Haz.). İsmet Miroğlu, İstanbul: Bereket Yayınevi.

Tunaşar, S. (2003). Osmanlı Devleti'nde Son Dönem Mason Sadrazamları ve Yönetime Etkileri. İstanbul: Piramit Yayınevi.

Uzunçarşılı, İ. H. (2010). Osmanlı Tarihinden Portreler, İstanbul, Yapı Kredi Yayınları.

Pakalın, M. Z. (1942). Son Sadrazamlar ve Başvekiller. İstanbul: Ahmet Sait Matbaası.

Süreyya, M. (1996). Sicill-i Osmani. (Yay.). Nuri Akbayar. İstanbul: Tarih Vakfı Yurt Yayınları.

Aydın, M. (1994). Doksanüç Harbi. Türkiye Diyanet Vakfı İslam Ansiklopedisi, Cilt: 9, 498-499.

Aydın, M. (1994). İbrahim Edhem Paşa. Türkiye Diyanet Vakfı İslam Ansiklopedisi, Cilt:10, 418-420.

Eldem, E. (2010). Bir Biyografi Üzerine Düşünceler: İbrahim Edhem Paşa Rum Muydu?. Toplumsal Tarih 202, 2-12.

Eldem, E. (2018). Sadrazam İbrahim Edhem. Erişim Adresi: https://tr.ambafrance.org/Sadrazam-Ibrahim-Edhem.

İnalcık, Halil, (1999). Hüsrev Paşa, Koca. Türkiye Diyanet Vakfı İslam Ansiklopedisi, Cilt: 19, 41-45.

Koç, H. (1992). Bir Belge Işığında İbrahim Edhem Paşa ve Ailesi Hakkında Hatırlamalar. Osman Hamdi Bey ve Dönemi 17-18 Aralık 1992 (Yay.). Zeynep Rona. İstanbul: Tarih Vakfı Yurt Yayınları, 27-40. Küçük, C. (1988). Abdülmecid. Türkiye Diyanet Vakfı İslam Ansiklopedisi, Cilt:1, 259-263.

Uzunçarşılı, İ. H. (2013). İbrahim Edhem Paşa Ailesi ve Halil Edhem Eldem. Halil Edhem Hatıra Kitabı, Ankara: Türk Tarih Kurumu Yayınları. 